\title{
Surveying the historical landscape: the evaluative voice of history textbooks
}

\author{
Gordon Myskow
}

Correspondence:

gmyskow@gmail.com

Department of Law and Political

Science, Keio University, 4-1-1

Hiyoshi, Kohoku Ward, Yokohama,

Kanagawa 2238521, Japan

\begin{abstract}
Much attention has been devoted to understanding the rhetorical features of history texts and how they position readers to take up particular views toward the past. One useful taxonomy for investigating evaluative meaning from the systemic-functional tradition is the Appraisal framework. Voice Theory extends this framework to account for the particular combinations of Appraisal resources that tend to occur in different genres and at specific stages within them, showing how authors take up various evaluative postures or 'voices' when communicating with their audiences. The Voices of History framework identifies a variety of such voices including Recorder and Interpreter that describe the particular configurations of Appraisal found in different history genres. Recent research, however, has shown that the types of Appraisal resources that commonly occur in history textbooks do not fit neatly with the existing Voices of History framework - a set of resources that was initially developed to describe the voices of written school history genres. This paper elaborates the Voices of History framework by proposing a new voice called Surveyor Voice to account for the types of Appraisal commonly deployed in history textbooks. It also discusses the modified framework in the context of broader disciplinary issues in historiography, including the underlying epistemological principles of historical knowledge construction.
\end{abstract}

Keywords: Appraisal framework, Voice theory, Historical discourse, History textbooks, Affect, Historical significance

\section{Background}

The Voices of History framework outlined in Coffin (2006, 150-151) offers a powerful set of tools for illuminating how authors of historical texts take up different evaluative postures, or "voices" in various history genres (see also Coffin 2000, 381-399). Using the Appraisal framework (Martin and White 2005), Coffin (2000, 394) identifies four voices of history: Emoter; Recorder; and the two Appraiser subtypes, Interpreter and Adjudicator. According to Coffin (2006, 150-151), each of these voices or "textual personas" is realized by specific combinations or "conventionalized clusterings" of different types of Appraisal resources. While the Emoter Voice, for example, is marked by a high frequency of Affect (e.g., sad, happy) and tends to occur in personalized genres such as autobiographies, the Appraiser voices are characterized by a preference for explicit judgment (e.g., brave, cruel) and are found in more argumentative genres (see also Ngo and Unsworth 2015 for recent revisions to the Appraisal framework).

(c) The Author(s). 2017 Open Access This article is distributed under the terms of the Creative Commons Attribution 4.0 International License (http://creativecommons.org/licenses/by/4.0/), which permits unrestricted use, distribution, and reproduction in any medium, provided you give appropriate credit to the original author(s) and the source, provide a link to the Creative Commons license, and indicate if changes were made. 
The Voices of History framework (Coffin 2006, 150-151) was developed to account for the evaluative features of written school history genres, showing how learners are expected to take up different voices or "textual personas" as they produce various genres at different stages of schooling (see also Llinares, Morton, and Whittaker 2012, 132-146; Christie and Derewianka 2008, 86-148 for systemic functional descriptions of school history genres). While this research provides much insight into the voices that learners use when writing about history, little is known about the voices they are exposed to when reading about history (for studies examining other linguistic features of history textbooks see Coffin and Derewianka 2008; Derewianka and Coffin 2008; Barnard 2000, 2003; Cullip 2007; de Oliviera 2010, 2012; Fitzgerald 2014; Hashiba 2010; Martin 1993; Martin, Maton, and Matruglio 2010; Moss 2010; Myskow, in press; Oteiza 2003; Tann 2010; Unsworth 1999; Veel and Coffin 1996).

This paper reports findings from a larger research project examining Appraisal in history textbooks (Myskow, 2015). The study found a specific configuration of Appraisal resources commonly used in history textbooks that is not identified in the current framework. To account for this combination of Appraisal resources, a new voice, referred to as Surveyor Voice, is proposed. The discussion begins by outlining the Appraisal and Voices of History frameworks. It then illustrates the features of Surveyor Voice by examining brief excerpts from history textbooks. The paper concludes by looking at the modified framework in the context of broader disciplinary issues in historiography, including the underlying epistemological principles of historical knowledge construction.

\section{Section 1: The appraisal framework and historical discourse}

The Appraisal framework, as outlined in Martin and White (2005), is comprised of three interacting domains of evaluative meaning: Engagement; Graduation; and Attitude. The resources of Engagement and Graduation perform dialogical functions, accounting for how "speakers/writers adopt a stance towards the value positions being referenced by the text and with respect to those they address" (Martin and White 2005, 92). While Engagement deals with the unfolding dialogical interplay among different viewpoints in texts, Graduation is concerned with the ways value positions are adjusted or graduated in terms of their strength and precision (see Martin and White 2005, 92160 for a detailed discussion of these resources).

The Attitude domain of Appraisal is, according to Martin and White (2005, 42), a means of "mapping feelings as they are construed in English texts". These feelings or attitudes operate on a positive/negative binary and include construals of Affect (emotions), Judgment (of people), and Appreciation (of things). Subcategories of Affect, as outlined in Ngo and Unsworth's recent (2015) modifications of this system, are Dis/Inclination, (want, unwilling) In/Security (fear, confident) Un/Happiness (joyful, sad), and Dis/Satisfaction (angry, content). In their description of the resources of Judgment, Martin and White (2005) draw a critical distinction between the ethics-oriented evaluations of Social Sanction that include Propriety (fair, corrupt) and Veracity (truthful, dishonest) and the less contentious judgments of Social Esteem that are codified by evaluations of Normality (popular, strange), Capacity (smart, foolish), and Tenacity (brave, shy). 
One area of the Appraisal framework that has presented some challenges accounting for discipline-specific appraisals of historical subject-matter is the Appreciation network (see Coffin 2000, 2006; Myskow 2015; Oteíza and Pinuer 2013, 2016 for attempts to address these issues). Coffin $(2000,278)$ proposes the category Social Valuation to describe the group of meanings concerned with "explicitly realised cause, time and change" (major/minor, significant/insignificant). However, as Coffin (2000, 277) points out, unlike the other resources of Appreciation that operate on a positive/negative polarity (e.g., terrible/wonderful), Social Valuation seems to implicate "a low to high distinction". Coffin (2000:278) acknowledges that treating some attitudinal values on a high/low parameter rather than a positive/negative polarity results in some degree of imbrication between Attitude resources and the Graduation network-the region of Appraisal concerned with how attitudinal meanings can be "upscaled/downscaled" in terms of "force" or "focus" (Martin and White 2005:135). However, Coffin (2000: 278) distinguishes between "a realisation of measure in the wider culture" that is dealt with in the Graduation network from discipline-specific historical meanings of measure that express institutional values, concluding that history-oriented measurements should be dealt with in the Appreciation network so as to capture their "disciplinary salience and resonance" (see Oteíza and Pinuer 2013 for an account of history-oriented resources in the Graduation framework).

Myskow (2015) elaborates Coffin's (2000, 2006) Social Valuation subcategory of Appreciation to include a range of meanings for expressing historical significance that operate on a high/low parameter (see Oteiza and Pinuer 2016 for an alternative attempt to locate high/low and positive/negative historical meanings in the Appreciation framework). This revised network is referred to in Myskow 2015 as Significance (see also Ngo and Unsworth's 2015 account of significance as an Appreciation subcategory). Drawing on historiographers' categorizations of the types of historical significance (e.g., Partington 1980; Phillips 2002) and Seixas' (1997) analogy of significance as a "terrain" or landscape where historical entities are graded in terms of their comparative impact, Myskow (2015) proposes the following subcategories of Significance:

1) Salience (e.g., major/minor)

2) Depth (e.g., profound/unremarkable)

3) Quantity (e.g., massive/negligible)

4) Distribution in time (e.g., longstanding/short-lived) and space (e.g., widespread/limited)

\section{Section 2: The voices of history framework}

Developed initially by Iedema et al. (1994) to describe the patterning of Appraisal choices in news discourse, Voice Theory is defined by Coffin $(2006,150)$ as "a means of capturing the conventionalized clusterings of [Appraisal] resources that occur within particular discourse domains and in relation to particular genres". Coffin's $(2000,394)$ framework posits the following four voices of history: Emoter; Recorder; and the two Appraiser subtypes, Interpreter and Adjudicator. Each of these voices is illustrated below using brief excerpts from history textbooks and scholarly works. For the purpose of consistency with other research, the following Appraisal color coding system from 
Coffin's $(2000,132)$ research has been adapted in the present study: Graduation (RED); Engagement subtypes of Expand (AQUA) and Contract (LIME); Attitude subtypes of Affect (PINK); Judgments of Social Esteem (BLUE), and Social sanction (PURPLE). As Coffin's (2000) work uses green for both Social Valuation and the superordinate category Appreciation, these two are differentiated here by using BROWN for high/low Significance and (GREEN) for positive/negative Appreciation.

The Emoter voice, according to Coffin $(2006,156)$, is "a minor voice" marked by "high levels of affect" and is mainly found in "autobiographical recounts or texts produced in response to tasks that aim to develop empathetic understanding". A distinguishing feature of Affect employed in these genres is that it "is generally used to express the writer's own inner emotional state and is therefore 'author oriented"' (Coffin 2006, 156). While Myskow's (2015) Appraisal analysis of history textbooks found that authors themselves do not express emotion toward the subject matter, the authororiented Affect associated with Emoter Voice can be found in adjunct autobiographical source materials in textbooks. The following excerpt from a source text in a US secondary school textbook reports the recollections of musician Cesar Rosas' experiences as a recent immigrant to the US in the 1950s and contains several instances of author-oriented Affect including negative Security (afraid, panicked) and positive Happiness (loved).

(1) When I came to the United States as a kid I really loved (+happiness) music and Rock and Roll... But coming to the United States-I'll never forget that! I was afraid (-Security)...I was panicked (-Security)

(As cited in Downey 2006, 219).

Unlike the Emoter Voice that construes the subjective feelings of the author, the Recorder Voice is characterized by an absence of all types of explicit Appraisal, lending it a "factual or neutral 'feel" (Coffin 2006, 151). This voice, according to Coffin (2006, 151), is most common in recording genres such as the Historical Recount where there is an "absence of direct, explicit forms of interpretation and the exclusion of competing, alternative interpretations". The following excerpt from a textbook section about twentieth-century Somalian history, for example, contains no explicit realizations of Attitude or dialogical resources for engaging with alternative perspectives:

(2) The Republic of Somalia was created in 1960 by unifying the former British Somaliland protectorate and the Italian Trusteeship Territory of Somalia. Nine years later, in a bloodless military coup, the Marxist Somali Revolutionary Socialist Party took power and renamed the country the Somali Democratic Republic (Quinlan et al. 2003, 201).

Coffin $(2000,396)$ is careful to emphasize that the disinterested impartiality of Recorder Voice does not imply that it is neutral or bias-free, and even goes so far as to call its appearance of neutrality a "discursive construction, a rhetorical trick".

In contrast with the Recorder Voice, the Appraiser Voices (Interpreter and Adjudicator) employ language that is more explicitly evaluative, thus bringing the subjective views of the authorial voice to the surface of the text (Coffin 2006, 152). According to Coffin (2006, 151), this voice is marked by the free occurrence of Judgments of Social Esteem and Social 
Valuation, the latter referred to here as Significance. Example (3) is an excerpt from a section of a history textbook describing Peter the Great's impact on Russian society:

(3) The greatest (+ Normality) of the Romanovs was Tsar Peter the Great (r. 1689-1725), who made major (Significance) changes to reduce Russia's isolation and increase the empire's size and power (Bulliet et al. 2008, 625).

In this brief excerpt (3), the views of the authorial voice are very much apparent. A positive loading of Normality (greatest) and high Significance (major) are used to offer a highly favourable evaluation of the Tsar and his impact on Russia.

The other Appraiser voice (Adjudicator) differs from Interpreter in that in addition to judgments of Social Esteem it also includes the more contentious, ethics-oriented Judgments of Social Sanction (i.e., Veracity and Propriety). Another feature of this voice, according to Coffin $(2006,153)$, is the use of resources of Engagement to negotiate reader-writer alignment with the high-stakes, morally-charged evaluations being advanced (see Miller et al. 2014, 2016 for recent discussions of Engagement in written student essays). As Myskow (2015) points out, however, neither Social Sanction nor the dialogical resources of Engagement are common in history textbooks, which tend to present more consensus-based, uncontentious views of the past. Therefore, rather than a textbook passage, the following excerpt from a scholarly work on post-war Japan is shown here to illustrate the features of the adjudicator voice:

(4) S1) There was no (Deny) counterpart [in Japan] to the principled (+ Propriety) resistance that a small but (Concur-Counter) heroic (+ Propriety) number of intellectuals, leftists, church people, and military officers had mounted against National Socialism in Germany [during the war]...S2) To many (Attribution) ordinary ( + Normality) Japanese of the "good morals (+ Propriety) and manners ( + Normality)" persuasion, the sudden postsurrender appearance of intellectuals, politicians, and a host of other public figures spouting paeans to democracy and demilitarization smacked of hypocrisy (- Veracity) and opportunism (- Propriety)

(Dower 1999, 234).

This highly contentious passage (4) contains five instances of Social Sanction, including four of Propriety (principled, heroic, good morals, opportunism), and one of negative Veracity (hypocrisy). These high-stakes judgments are mediated through the use of contractive and expansive Engagement resources. S1 contains the contractive resource Deny, which according to Martin and White $(2005,118)$ is "a resource for introducing the alternative positive position into the dialogue, and hence acknowledging it, so as to reject it". It is used here to tease out, then summarily dismiss the opposing view that Japan had a large number of dissenters during the war. Also in S1 is the dialogical pairing, Concur-Counter, whereby the authorial voice concurs with the potential objection that the antiwar movement in Germany was small, before reclaiming the argumentative ground by inventorying the various heroic groups involved in the movement. The dialogically expansive resource, Attribution, in S2 is used to provide some 'rhetorical cover' for the author by sourcing the strongest evaluations (hypocrisy, opportunism) to the hearsay of many ordinary Japanese. It should be noted that the high-stakes, ethics-based orientation of the Adjudicator Voice does not imply that it is more privileged or esteemed among members of the history profession than the somewhat less axiologically charged Interpreter Voice. As excerpt (4) illustrates, however, the potentially contentious, moral nature of the claims being advanced by Adjudicator Voice may 
necessitate considerable dialogical 'work'-vis-à-vis the resources of Engagement-to persuade potentially reticent readers of their legitimacy.

The four voices outlined here (Emoter, Recorder, Interpreter, Adjudicator) provide much insight into the interpersonal strategies available to authors of various history genres to communicate their views of the past. However, as the following section shows, this framework does not adequately account for the types of evaluative features commonly found in history textbooks.

\section{Section 3: The voices of history framework and history textbooks}

Myskow's (2015) Appraisal analysis of secondary school and university history textbooks found that the two most frequent types of Appraisal resources used in these texts are Significance and Affect. Myskow (2015) points out that while the high frequency of Significance is not surprising as the identification of significance is central to historical inquiry, the high occurrence of Affect was rather unexpected. (see also Oteíza 2003 for a discussion of Affect in history textbooks). As Myskow 2015 also observes, however, the Affect found in history textbooks is, in Coffin's $(2000,156)$ terms, "non author oriented"-that is, it is sourced to historical participants rather than the authorial voice.

According to Myskow (2015), many of the instances of Affect in the textbook corpus take the form of nominalized textual assimilations, as in the invented example, 'a climate of distrust and anxiety'. These findings are consistent with the results of Oteiza's (2003) investigation of the Appraisal features of Chillean history textbooks that found nominalized Affect to be commonly used in descriptions of major socio-political conflicts. Other findings of Myskow's (2015) Appraisal analysis of history textbooks include a low frequency of Judgment-the resources for evaluating people and their behavior.

These configurations of Appraisal resources in history textbooks do not fit neatly in Coffin's existing Voices of History Framework, which, as mentioned previously, was developed to account for the evaluative features of different types of written genres in school history. One reason is that in the existing framework, a high frequency of Affect is associated with the Emoter Voice, but as Coffin $(2000,393)$ points out, this voice is "a more marginal voice" that "is generally used to express the writer's own inner emotional state and is therefore 'author oriented". This type of Affect is markedly different from the non-author-oriented Affect of history textbooks that is often realized in complex nominal formulations.

Another issue has to do with the aforementioned low frequency of Judgment in history textbooks. Of the three categories of Attitude (Affect, Appreciation and Judgment), Myskow (2015) found the occurrence of Judgment to be considerably lower than the others. But according to Coffin $(2000,394)$, the resources of Judgment are a distinguishing features of the Appraiser voices (Interpreter and Adjudicator). While Interpreter voice is characterized by a "median probability of inscribed social esteem", Adjudicator is marked by the "free occurrence of un-attributed social sanction and social esteem" (Coffin (2000, 394). As Affect was found to be far more common than Judgment in Myskow's (2015) corpus, neither of the Appraiser voices adequately capture the most salient evaluative features of history textbooks. Moreover, the Recorder Voice, which is marked by a low occurrence of all types of Attitude, does not describe this configuration of Appraisal resources found in textbooks either.

A third issue with applying Coffin's framework to history textbooks is related to the high frequency of high/low Significance (i.e., Social Valuation). In Coffin's Voices of History 
framework, a high probability of Social Valuation is one of the features that distinguishes the Appraiser voices (Interpreter and Adjudicator) from the Emoter and Recorder voices which both have a low probability of Social Valuation. However, as pointed out previously, there is a critical difference between evaluative acts that operate on a high/low parameter (e.g., major, important) and those that are categorized in terms of a positive/negative polarity (e.g., worthwhile, splendid) (see Bednarek 2009 for an in-depth discussion of this issue). The use of a high/low parameter rather than a positive/negative binary enables the authorial voice to simultaneously intrude into the text, showing an historical 'mind at work, whilst maintaining a posture of aloofness and neutrality. This is illustrated in the following excerpt (5) that shows a portion of the concluding segment of a university textbook chapter discussing the effects of WWI on the US and Russia.

(5) S1) Internationally, the First World War had especially dramatic impacts (High Significance) on the United States and Russia. S2) Although it remained officially neutral until 1917, the US provided financial loans to Britain and France to assist in their war efforts, and this massive (Significance) transfer of wealth transformed (Significance) the US from a debtor nation into a major (Significance) creditor. S3) Although it would take another generation for the US to become a dominant (Significance) world power, its intervention in the war contributed to a larger shift (Significance) in political influence away from Europe... S4) These events had profound implications (Significance) not only for Russia, which was forced into civil war, but also for countries around the world.

(Keylor et al. 2011, 59)

In Excerpt (5), the impact of events on the US and Russia are shown as significant in terms of their Salience in the historical landscape (major, dominant), their Depth of impact (dramatic, transformed, profound), their Quantity (massive) and their Distribution across space (a larger shift). But despite these numerous evaluations, the authorial voice of this text is a cautious and circumspect one, avoiding explicit value-laden views of the emergence of US power after WWI. When these instances of Significance in (5) are substituted with resources of Attitude on a positive/negative binary rather than a high/ low parameter, a very different evaluative voice emerges:

(6) 1) Internationally, the First World War had especially positive/negative (+/-Appreciation) impacts on the United States and Russia. 2) Although it remained officially neutral until 1917, the US provided financial loans to Britain and France to assist in their war efforts, and this generous/ unnecessary ( $+/$-Appreciation) transfer of wealth transformed the US from a debtor nation into an effective/bungling (+/-Capacity) creditor. 3) Although it would take another generation for the US to become a capable/fumbling ( $+/$-Capacity) world power, its intervention in the war contributed to a fortunate/unfortunate (+/-Appreciation) shift in political influence away from Europe. 4) These events had positive/negative ( + -Appreciation) implications not only for Russia, which was forced into civil war, but also for countries around the world.

(Adapted from Keylor et al. 2011, 59)

As the modifications in (6) show, substituting high Significance with realizations of positive/negative Attitude results in a far more contentious, attitudinally charged text. Considering these issues in applying the Voices of History framework to textbooks, it seems necessary to propose a new, intermediary voice between Recorder and Interpreter that is characterized by a high occurrence of the resources of Significance and Affect. 


\section{Section 4: A revised voices of history framework}

By employing the resources of Significance, the authorial voice takes up the inter-subjective persona of a neutral observer, charting the peaks and valleys of the "historical terrain" (Seixas 1997), but not intruding directly to offer its own positive/negative assessments of them. As mentioned previously, this landscape can be conceptualized in terms of the extent to which events stand out in it by virtue of their Salience, Depth of impact, Quantity or Distribution across it in both space and time (see Myskow 2015). A key feature of these evaluations, therefore, is the more distant perspective that the authorial voice takes as its vantage point from the historical landscape, evaluating the terrain in terms of broad patterns of cause, time and change. This contrasts with the more 'local' position typically taken up by the Recorder Voice, from which particular events are listed chronologically 'as they happened'.

Likewise, the nominalized instances of Affect typically deployed in these texts are not that of a sentient, expressive individual; rather, they are the contours of collectivized human responsiveness-mounds of emotive material that are only discernible from a distance, through the reductionist lens of historical perspective. In taking up evaluations of high/low Significance and non-author oriented Affect, the authorial voice fashions itself as a disinterested topographer or surveyor of the historical landscape. The proposed voice that aims to account for these features, therefore, is referred to here as Surveyor Voice.

The revised Voices of History framework shown in Fig. 1 locates Surveyor Voice at an intermediary position between the 'disinterested,' 'objective' Recorder Voice and the intrusive, attitudinally-invested Appraiser Voices. As the following discussion shows, Surveyor Voice is a key evaluative persona of history textbooks, which are sometimes aptly referred to as surveys in titles such as A Concise Survey of Western Civilization (Pavlac 2011).

Before illustrating how Surveyor Voice is used in history textbooks it should be pointed out that unlike Coffin's $(2000,2006)$ research, the purpose of the present study is not to map the different voices onto history genres or genre families (i.e., recording, explaining, arguing). As Coffin (2006, 62-63) points out, the identification of genres in history textbooks is complicated by the fact that "different stages of the genre may be spread across chapters or sections within a chapter". Thus, rather than trying to extract genre fragments-or in Veel and Coffin's (1996, 201) words "bleeding chunks"-from textbook chapters, the present investigation confines itself to the patterns of Appraisal across stretches of text. Nevertheless, as the following discussion shows, Surveyor Voice appears to be especially prevalent in particular sections of chapters including the introduction and other segments oriented toward explaining the past.

Surveyor Voice was identified in the introductory sections of all four of the textbooks chapters analysed in Myskow's (2015) study. Excerpt (7) below is from the introductory section of a university textbook discussing the impact on Canada of the country's entry into WWI:

(7) S1) Canada's entry into World War I marked (Significance) a triumph (+Appreciation) of sorts for Canadian imperialism. S2) It also rejuvenated ( + Inclination) Canadian reformers. S3) Canada had played very little direct part (Significance) in the events leading up to the war. S4) Nonetheless, the war was in many respects a watershed (Significance) for Canadians...S5) Together, the patriotic fervour (+happiness) of the war and the eventual political isolation of French Canada, sealed (Significance) by the Conscription Crisis of 1917, made possible a sweeping (Significance) program of reform, much of which French Canadians had opposed.

(Bumsted 2014, 198) 


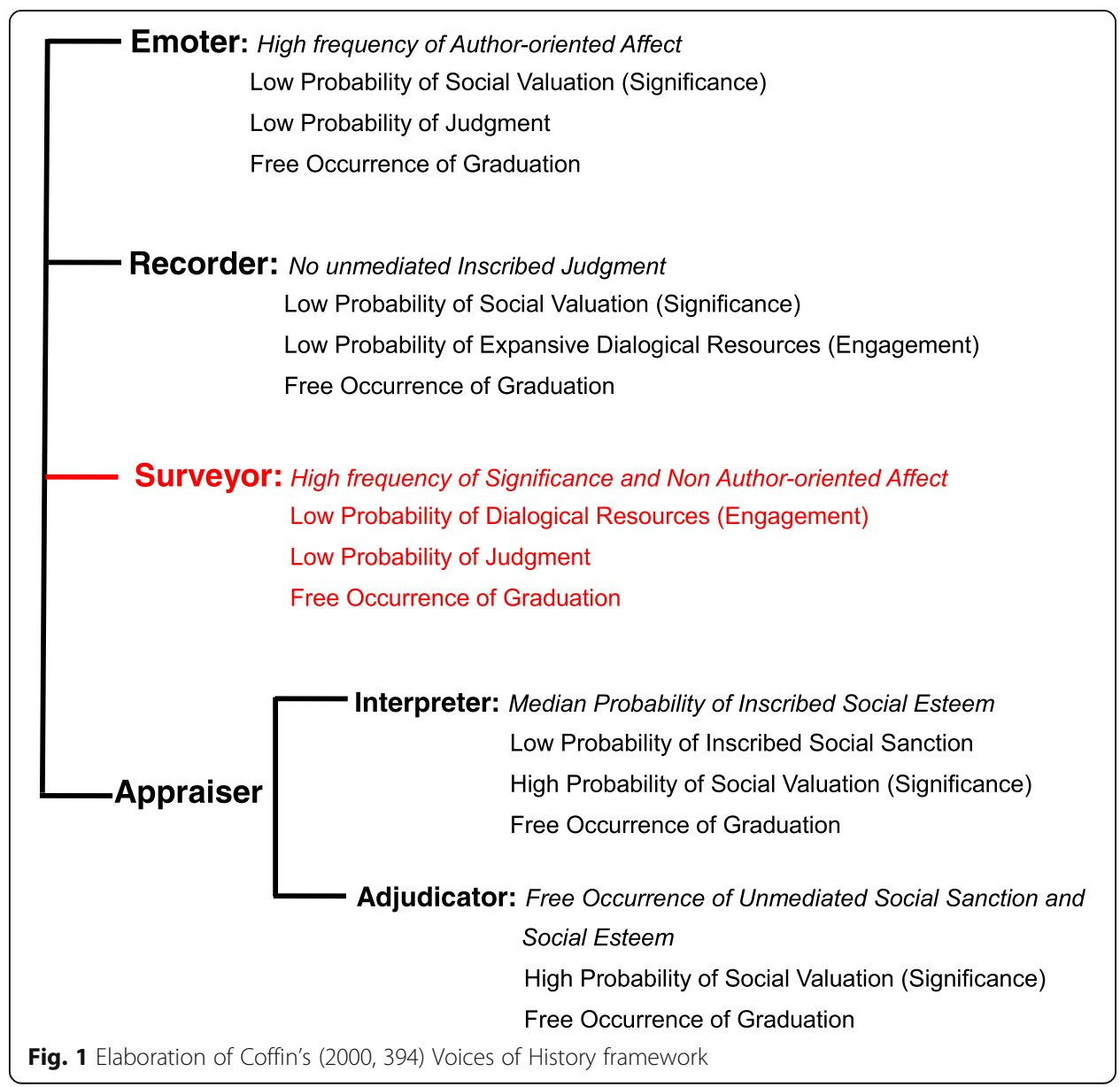

In this excerpt (7) the author mostly avoids commenting explicitly on the positive or negative effects of Canada's entry into the war. Instead, evaluations of Significance (marked, watershed, sweeping) and Affect (rejuvenated, patriotic fervour) are the voice of a surveyor inspecting the terrain of historical significance and examining the mounds of collective emotions. While there are some instances of Engagement signalled by nevertheless (S4) in the Concur element of the Concur-Counter pairing, as well as the Graduation resources of Focus in of sorts (S1) and Force in many respects (S4), overall the text is not overtly dialogical. Its main function is to draw the contours of the historical landscape, construing, rather categorically, the impact of the war on Canadians. The only other type of evaluation in this passage (7) is the instance of positive Appreciation realized by the noun triumph. But the evaluative force of this attitudinally-charged resource is blunted by the context in which it occurs. The notion that the First World War could be a triumph for Canadian imperialism is an ironic one-that so many citizens of such a sparsely populated nation, not known for its colonial prowess, relocated to Europe to participate in the war serves to emphasize the large scale (i.e., significance) of the conflict, rather than the author's positive view of its impact.

The high frequency of Significance in the introductory segments of history textbooks is perhaps unsurprising. The tendency to highlight the subject-matter of introductions for its significance has been observed in other genres. Swales' $(1990,142)$ oft-cited analysis of research article introductions, for example, shows how the first move of the introduction, referred to as "establishing a territory", is marked by "the need to re-establish in the 
eyes of the discourse community the significance of the research field itself, [and] the need to situate the research in terms of that significance". In the introductions to the history textbooks analysed here, the Surveyor Voice performs a similar function to establish the significance of the events in the chapter so that readers may understand their importance and thus, why they are to read about them.

Other areas of textbooks where the Surveyor Voice was found to commonly occur are segments that function to explain the causes and effects of historical outcomes. In their analysis of historical texts, Oteíza and Pinuer (2013) observe how the coupling of Graduation resources that operate on a high/low parameter with Attitude in explanatory segments of text can "infuse urgency and drama in the discourse". The following excerpt (8) from a secondary school textbook explaining the events that led to the First World War illustrates how the interaction between high/low Significance and Affect can create a feeling of rising tension:

(8) S1) As 1914 approached, the international power struggle became more intense (Significance).

S2) One incident followed another and each contributed to the mounting (Significance) tension

(-Security) and hostility (-Security) between the European powers. S3) The humiliation

(-Happiness) of defeat in the Russo-Japanese War in 1905 refocused (Significance) Russian

interests on Europe, particularly the Balkans states... S4) In 1912 the situation changed

dramatically (Significance). S5) A Balkan league was formed under the leadership of Serbia... S6)

The rise of Serbian power concerned (-Security) Austria-Hungary. S7) These fears (-Security)

were heightened (Significance) in 1913 when another Balkan war erupted (Significance).

(Quinlan et al. 2003, 38)

As the analysis of (8) shows, there is a strong co-occurrence of Significance (intense, mounting, changed dramatically, erupted, heightened) and Affect (tension, hostility, humiliation, concerned, fears). The extensive use of these resources enables the authorial voice not just to assess the comparative historical weight of these developments but to establish a causal chain in which key events (i.e., Significance) and human responses to them (i.e., Affect) build on one another, propelling the causal explanation forward to the eventual eruption of another Balkan War (see Fitzgerald 2014 for an in-depth discussion of causation in historical discourse). Oteiza and Pinuer $(2013,54)$ use the term "Acceleration" to describe how these features "create a sense of rapid progression of time towards a situation of uncontrollable crisis". Unlike the comparatively subdued and 'objective' Recorder Voice, therefore, Surveyor Voice has the effect of creating dramatic suspense as events move toward a climactic conclusion. However, despite this extensive use of Appraisal resources, Surveyor Voice is considerably more restrained and conservative than the Appraiser voices (Interpreter, Adjudicator) because the authorial voice itself does not intrude in the text to offer positive/negative evaluations of the discourse under construction.

That the Surveyor voice has been identified in textbooks is perhaps not surprising. Provenzo et al. $(2011,1-8)$ refer to textbooks as "consensus documents" for their reluctance to "alienate their audience", and note that they "are not only social and cultural documents but are part of a highly charged political and social discourse". Surveyor voice is a particularly useful rhetorical tool for textbook writers to show there is an historical mind at work, but a careful, uncontroversial one that is able to appeal to diverse audiences. Hyland $(2005,101)$ discussing the discourse of textbooks more generally observes that they are "widely regarded as repositories of codified facts and disciplinary orthodoxies... 
the places where we find the tamed and accepted theories of a discipline" (see also Myers 1992 and Biber and Conrad 2010, 126-129).

To sum up, Surveyor Voice, located at an intermediary point between the Recorder and Appraiser Voices, goes beyond a local, factual description of events (Recorder Voice) to grade larger patterns of cause, time, and change on the historical landscape in terms of their relative significance. However, it stops short of evaluating the historical subjectmatter vis-à-vis the positive/negative binary that characterizes Appraiser voices. Thus, Surveyor Voice is a rather conservative one in that it does not fully exploit the available Appraisal resources to perform good/bad evaluations of people and events.

\section{Section 5: Voice theory and epistemology of history}

Historiographer, Paul Ricoeur (2004), identifies three main stages of knowledge construction in the history discipline: 1) the documentary phase; 2) the explanation/understanding phase; and 3) the representative phase. Together, these activities comprise the epistemological base of the history profession, or what Ricoeur $(2004,136)$ refers to as "the historical operation" (see Myskow (in press) for a related discussion of Ricoeur's notion of the historical operation and its relevance to other evaluative features of historical discourse). Ricoeur $(2004,137)$ emphasizes that historians do not necessarily proceed from one stage to the next in a linear fashion; rather, he postulates that these stages are non-linear, "methodological moments interwoven with one another". As the following discussion shows, these 'methodological moments' are discernible in the different voices taken up in history texts.

The first of Ricoeur's $(2004,136)$ stages of the historical operation, the documentary phase, is concerned with "the establishment of documentary proof" and "runs from the declarations of eyewitnesses to the constructing of archives". As pointed out in the previous section, the Emoter Voice is typically found in primary source materials such as autobiographical accounts, letters and diaries that are written from the perspective of historical participants and integrated into the historical work by the authorial voice. As such, it is concerned with the reactions or 'raw emotion' of historical actors, and thus can be associated with the primary source materials or 'eyewitness' documents of the archive from which historical interpretations are based. The archive-oriented knowledge of this stage also implicates Recorder Voice. With its disinterested factual orientation and chronological sequencing, Recorder Voice invokes the discourse of annals-the historical records that often serve as the archives for further historical inquiry (see White 1987 for an in-depth discussion of annals and other types of historical discourse).

The second phase of Ricoeur's $(2004,136)$ historical operation, explanation/understanding, is, as he puts it, concerned with "responding to the question 'why?': Why did things happen like that and not otherwise?" According to Ricoeur (2004, 235), answering such questions requires adjusting the scale of historical description from a local to a more distant perspective. As Ricoeur $(2004,215)$ explains, local events in a village can be adjusted in scale by connecting them to larger economic or social patterns of change. Thus, this phase necessitates the historian withdrawing or 'zooming out' from the day-to-day lived experiences of historical actors to view the more generalized contours of historical change. This stage corresponds neatly to the Surveyor Voice, which is concerned with grading objects on the historical terrain in terms of their significance 
and with regard to larger patterns of change, time and cause. Also, Surveyor Voice tends to occur in portions of text dealing with explanation or 'the why?' of history.

The third phase, the representational phase, is more discourse-oriented and overtly dialogical than the others, involving "the putting into literary or written form of discourse offered to the readers of history" (Ricoeur 2004, 136). This phase goes beyond simply surveying the contours of the historical landscape to explicitly engaging with an envisioned disciplinary community, which involves "the mobilizing of probable arguments within the frame of the narrative, and the writer's concern to convince by persuading" (Ricoeur 2004, 236). The underlying epistemological orientation in this phase is reflected in the value positioning taken up in the Appraiser voices: Interpreter and Adjudicator. These voices, through the use of explicit inscriptions of Attitude and Engagement-the latter, especially prevalent in the Adjudicator Voice-advance the authorial view of the past and persuade readers of its merits.

Figure 2 summarizes how the different voices of history correspond to Ricoeur's three stages in the construction of historical knowledge. As apparent in Fig. 2, there is a progression from Emoter to Adjudicator Voice: from history-based archival knowledge to historian-based interpretive knowledge with Surveyor Voice occupying an intermediary position between the documentary and representational phases.

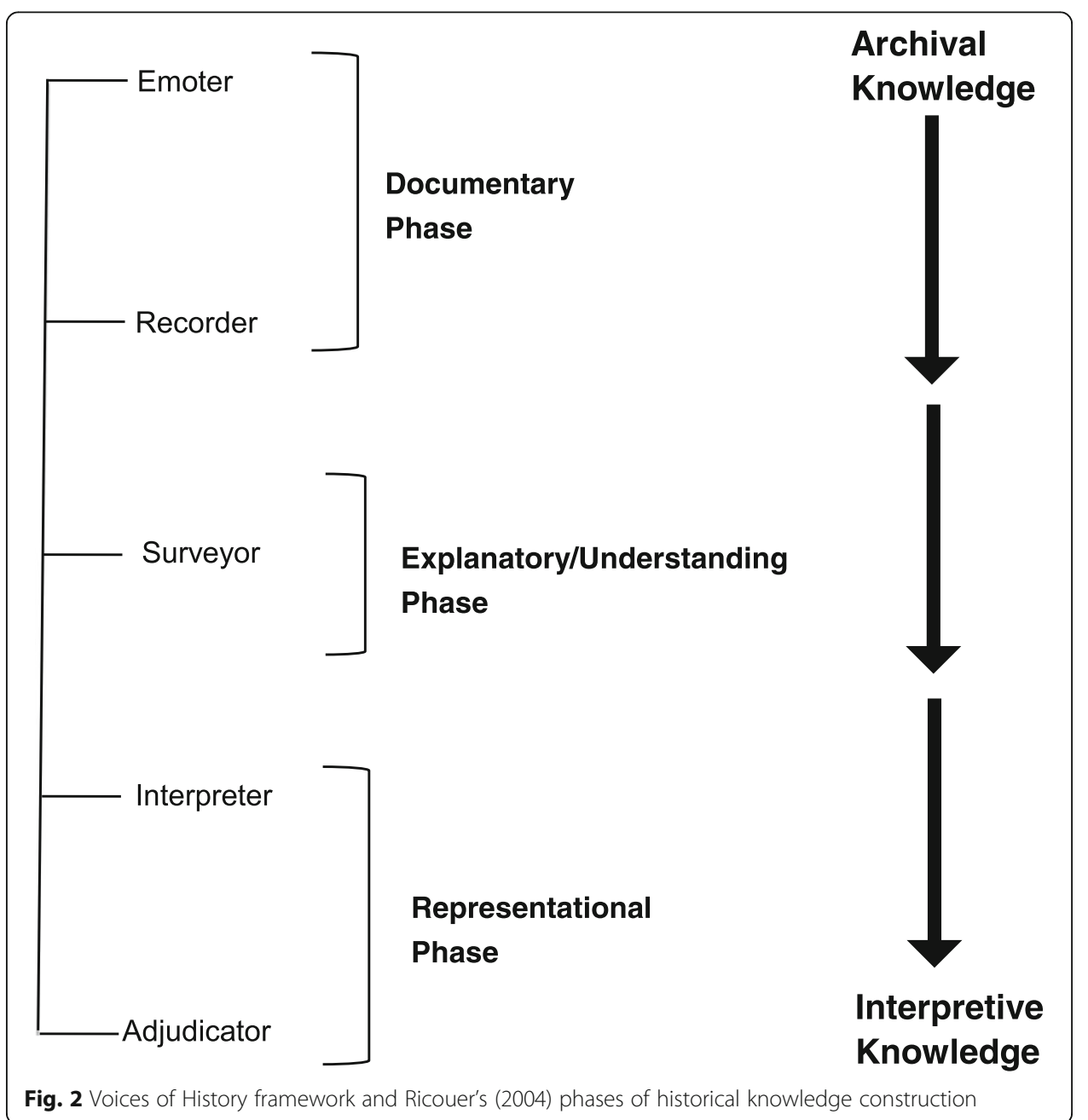




\section{Conclusion and implications}

This paper has elaborated Coffin's (2000, 2006) Voices of History framework to include Surveyor Voice-an intermediary voice between Recorder and Appraiser that is marked by a high probability of high/low Significance and non-author-oriented Affect. This voice appears to be strongly associated with textbooks, which typically provide general introductions or 'surveys' of historical periods, characterizing them in terms of generalized patterns of cause and change. Unlike Appraiser voices, Surveyor Voice stops short of fullfledged evaluations of people and things in terms of a positive/negative binary. However, it goes beyond the factual-oriented Recorder Voice to explicitly grade or weight various entities on the historical landscape in terms of their comparative significance.

The discussion also looked at the Voices of History framework in relation to the epistemology of historical representation, examining how the various voices correspond to key stages in the construction of historical knowledge. A progression was observed from Emoter to Adjudicator Voice-from history-based archival knowledge to historian-based interpretive knowledge.

These observations are of relevance not only to educational linguists but to history teachers, and possibly even the broader history profession. One implication for history educators is that the guarded, conservative voice modelled for students in their history textbooks is markedly different from the more argumentative ones (Interpreter and Adjudicator) that students are required to take up in their written essays, especially in the later years of schooling. While much has been made of the differences between textbooks and written genres, little attention has been paid to their divergent voices-the prudent and circumspect Surveyor Voice that speaks to learners through the historical narrative of their textbooks and the bold, discriminating personas novice writers are expected to simulate in their written essays. This underscores the need to supplement the input learners receive from their course materials with samples of actual texts they are required to write.

Insights from the Voices of History Framework may also be of relevance to members of the history profession interested in the relationship between their disciplinary activities and the linguistic features of the texts they produce. As the discussion in this paper shows, the Voices of History Framework provides a systematic approach to understanding the interpersonal functions of historical discourse. Moreover, it shows how the various disciplinary activities that historians undertake leave behind a discernible linguistic film or residue that is patterned in the language they use. Describing the ways language functions vis-à-vis the various voices historians take up for different audiences provides insight into how arguments are advanced and socio-rhetorical goals are achieved.

Acknowledgments

I am grateful to Susan Hunston for her valuable feedback on work leading to this paper. I also wish to thank the anonymous reviewers for their helpful suggestions on an earlier version of this article.

The author declares that he/she has no competing interests.

Received: 8 December 2016 Accepted: 27 January 2017

Published online: 11 March 2017

References

Barnard, Christopher. 2000. Protecting the face of the state: Japanese high school history textbooks and 1945. Functions of Language 7: 1-35. 
Barnard, Christopher. 2003. Pearl Harbor in Japanese high school history textbooks: the grammar and semantics of responsibility. In Re/reading the Past: Critical and Functional Perspectives on Time and Value, ed. Jim Martin and Ruth Wodak, 247-271. Amsterdam: Benjamins.

Bednarek, Monika. 2009. Language patterns and ATTITUDE. Functions of Language 16: 165-192.

Biber, Douglas, and Susan Conrad. 2010. Register, Genre and Style. Cambridge: Cambridge University Press.

Bulliet, Richard W., Pamela Kyle Crossley, Daniel R. Headrick, Hirsch, Stephen W. Hirsch, Lyman L. Johnson, and David Northrup. 2008. The earth and its peoples: a global history. Boston, Mass: Houghton Mifflin.

Bumsted, J.M. 2014. The Peoples of Canada: A Post-confederation History, 2nd ed. Don Mills, Ontario: Oxford University Press.

Christie, Francis and Beverly Derewianka. 2008. School discourse. London: Continuum.

Coffin, Caroline. 2000. History as discourse: Construals of time, cause and Appraisal. Unpublished PhD thesis, University of New South Wales, Australia.

Coffin, Caroline. 2006. Historical discourse: The language of time, cause and evaluation. London: Continuum.

Coffin, Caroline, and Beverley Derewianka. 2008. Multimodal layout in school history books: The texturing of historical interpretation. In Text-type and texture, ed. Gail Forey and Geoff Thompson, 191-215. London: Equinox.

Cullip, Peter F. 2007. Making history in Malaysian schools: how the pedagogic discourse of history functions in Malaysian classrooms. Journal of Curriculum Studies 39: 195-218. doi:10.1080/00220270500468452.

de Oliviera, Luciana C. 2010. Nouns in history: packaging information, expanding explanation and structuring reasoning The History Teacher 43: 191-203.

de Oliviera, Luciana C. 2012. What history teachers need to know about academic language to teach English language learners. Social Studies Review 2012: 76-79.

Derewianka, Beverley, and Caroline Coffin. 2008. Time visuals in history textbooks: Some pedagogic issues. In Multimodal semiotics: Functional analysis in contexts of education, ed. Len Unsworth, 187-200. London: Continuum.

Dower, John W. 1999. Embracing Defeat: Japan in the Wake of WWII. New York: W.W. Norton \& Company.

Downey, Mathew T. 2006. Contemporary's American History 2. Chicago: Mcgraw Hill.

Fitzgerald, Jason C. 2014. An analysis of causal asyndetic constructions in United States history textbooks. Functional Linguistics 1. doi:10.1186/2196-419x-1-5.

Hashiba, Erika J. 2010. The representation of World War II: a comparison of Japanese and American textbook discourse. Intercultural Communication Studies 14: 149-167.

Hyland, Ken. 2005. Metadiscourse. London: Continuum.

ledema, Rick, Susan Feez, and Peter R.R. White. 1994. Media literacy. Sydney, NSW: Disadvantaged Schools Program, Department of School Education.

Keylor, William, Jerry Bannister, and Tracey Kinney. 2011. The twentieth-century world: An international history. Don Mills, Ontario: Oxford University Press.

Llinares, Ana, Tom Morton, and Rachel Whittaker. 2012. The roles of language in CLIL. Cambridge: Cambridge University Press.

Martin, J.R. 1993. Life as a noun: Arresting the universe in science and the humanities. In Writing science: Literacy and discursive power, ed. M.A.K. Halliday and J.R. Martin, 221-267. London: Falmer.

Martin, J.R., and P.R.R. White. 2005. The language of evaluation: Appraisal in English. London/New York: Palgrave/ Macmillan.

Martin, James, Karl Maton, and Erika Matruglio. 2010. Historical cosmologies: Epistemology and axiology in Australian secondary school history discourse. Revista Signos 43: 443-463.

Miller, Ryan T., Thomas D. Mitchell, and Silvia Pessoa. 2014. Valued voices: Students use of engagement in argumentative history writing. Linguistics and Education 28: 107-120.

Miller, Ryan T., Thomas D. Mitchell, and Silvia Pessoa. 2016. Impact of source texts and prompts on students' genre uptake. Journal of Second Language Writing 31: 11-24.

Moss, Gillian. 2010. Textbook language, ideology and citizenship: the case of a history textbook in Colombia. Functions of Language 17: 71-93.

Myers, Gregory A. 1992. Textbooks and the sociology of scientific knowledge. English for Specific Purposes 11: 3-17. doi: 10.1016/0889-4906(92)90003-S.

Myskow, Gordon. 2015. Evaluative language in history textbooks. Unpublished PhD thesis: University of Birmingham, UK.

Myskow, Gordon (in press) A framework for analyzing evaluative meaning in historical discourse. Functions of Language. Accepted for publication May, 42016.

Ngo, Thu and Len Unsworth. 2015. Reworking the Appraisal framework in ESL research: Refining attitude resources. Functional Linguistics. doi 10.1186/s40554-015-0013-x.

Oteíza, Tereza. 2003. How contemporary history is presented in Chilean middle school textbooks. Discourse \& Society 14: 639-660.

Oteíza, Tereza, and Claudio Pinuer. 2013. Valorative prosody and the symbolic construction of time in recent national historical discourses. Discourse Studies 15: 43-64. doi:10.1177/1461445612466447.

Oteiza, Tereza, and Claudio Pinuer. 2016. Appraisal framework and critical discourse studies: a joint approach to the study of historical memories from an intermodal perspective. International Journal of Language Studies 10: $5-32$.

Partington, G. 1980. The Idea of an Historical Understanding. Slough, England: National Foundation for Educational Research.

Pavlac, Brian A. 2011. A Concise Survey of Western Civilization: Supremecies and Diversities throughout History. Lanham, Maryland: Rowman \& Littlefield Publishers.

Phillips, R. 2002. Reflective Teaching of History 11-18. London: Continuum.

Provenzo, Eugene F. Jr., Annis N. Shaver, and Manuel Bello. (2011). The textbook as discourse: sociocultural dimensions of American schoolbooks. New York: Routledge.

Quinlan, Don, Graham Draper, Pamela Perry-Globa, and Victor Zelinski. 2003. Twentieth century viewpoints: An interpretive history for the 21st century. Don Mills, Ontario: Oxford University Press.

Ricoeur, Paul. 2004. Memory, history and forgetting. London: University of Chicago Press.

Seixas, Peter. 1997. Mapping the terrain of historical significance. Social Education 61: 22-27. 
Swales, John M. 1990. Genre Analysis: English in Academic and Research Settings. Cambridge: Cambridge University Press.

Tann, Ken. 2010. Imagining communities: A multifunctional approach to identity management in texts. In New Discourse on Language, ed. Monika Bednarek and J.R. Martin, 163-194. London: Continuum.

Unsworth, Len. 1999. Developing critical understanding of the specialised language of school science and history texts: a functional grammatical perspective. Journal of Adolescent and Adult Literacy 42: 508-521.

Veel, Robert, and Caroline Coffin. 1996. Learning to think like an historian: The language of secondary school history. In Literacy in society, ed. Ruqaiya Hasan and Geoff Williams, 191-231. Harlow, Essex: Addison Wesley Longman.

White, Hayden. 1987. The content of the form: Narrative discourse and historical representation. Baltimore: John Hopkins University Press.

\section{Submit your manuscript to a SpringerOpen ${ }^{\circ}$ journal and benefit from:}

- Convenient online submission

- Rigorous peer review

- Immediate publication on acceptance

- Open access: articles freely available online

- High visibility within the field

- Retaining the copyright to your article

Submit your next manuscript at $\boldsymbol{\nabla}$ springeropen.com 